\title{
Rhodococcus kunmingensis sp. nov., an actinobacterium isolated from a rhizosphere soil
}

\author{
Correspondence \\ Wen-Jun Li \\ wjli@ynu.edu.cn \\ or \\ liact@hotmail.com
}

\author{
Yong-Xia Wang, ${ }^{1} \dagger$ Hai-Bin Wang, ${ }^{2}+$ Yu-Oin Zhang, ${ }^{1,3}$ Li-Hua Xu, ${ }^{1}$ \\ Cheng-Lin Jiang ${ }^{1}$ and Wen-Jun $\mathrm{Li}^{1}$
}

\author{
${ }^{1}$ The Key Laboratory for Microbial Resources of the Ministry of Education, PR China, and \\ Laboratory for Conservation and Utilization of Bio-Resources, Yunnan Institute of Microbiology, \\ Yunnan University, Kunming 650091, PR China \\ ${ }^{2}$ Zhejiang Hisun Group Co., Ltd, Taizhou, Zhejiang 318000, PR China \\ ${ }^{3}$ Institute of Medicinal Biotechnology, Chinese Academy of Medical Sciences \& Peking Union \\ Medical College, Beijing 100050, PR China
}

The genus Rhodococcus was classified into the family Nocardiaceae of the suborder Corynebacterineae (Stackebrandt et al., 1997). With the emergence of molecular identification methods, particularly 16S rRNA gene sequencing, the classification of the rhodococci has been greatly improved. For example, members of the genus Rhodococcus have been assigned to four 16S rRNA subclades, represented by Rhodococcus equi, Rhodococcus rhodnii, Rhodococcus rhodochrous and Rhodococcus erythropolis (McMinn et al., 2000), and the discovery of novel Rhodococcus species has been greatly facilitated. At the time of writing, more than 40 species are recognized and these micro-organisms exhibit broad metabolic diversity. In this study, the taxonomic position of an actinobacterium was examined by using a polyphasic approach. On the basis of phenotypic, chemotaxonomic and genotypic characteristics, it is proposed that strain YIM $45607^{\mathrm{T}}$ represents a novel species of the genus Rhodococcus.

Strain YIM $45607^{\mathrm{T}}$ was isolated from a soil sample collected from the rhizosphere of Taxus chinensis in Kunming by the following method. Soil samples were

†These authors contributed equally to this work.

The GenBank/EMBL/DDBJ accession number for the 16S rRNA gene sequence of strain YIM $45607^{\top}$ is D0997045. air-dried for 7 days; $1 \mathrm{~g}$ soil was then suspended in $50 \mathrm{mM}$ phosphate buffer ( $\mathrm{pH} 7.0$ ) containing $0.1 \%$ sodium cholate and incubated at $45{ }^{\circ} \mathrm{C}$ for $1 \mathrm{~h}$ with vigorous shaking in order to disperse soil aggregates and restrain the growth of fast-growing bacteria. The soil-water suspension was centrifuged and $0.1 \mathrm{ml}$ supernatant was resuspended in $9 \mathrm{ml}$ of the same sterile buffer before being spread on humic acid-vitamins-gellan gum (HVG) medium (Suzuki et al., 1999) and incubated at $28{ }^{\circ} \mathrm{C}$ for 30 days. The strain was cultivated on yeast extract-malt extract agar (ISP 2; Shirling \& Gottlieb, 1966) and maintained as a glycerol suspension $(20 \%, \mathrm{w} / \mathrm{v})$ at $-70{ }^{\circ} \mathrm{C}$.

To investigate its morphological properties, strain YIM $45607^{\mathrm{T}}$ was cultivated aerobically at $28{ }^{\circ} \mathrm{C}$ on ISP 2 . Cell morphology was examined by using light microscopy with a model BH-2 microscope (Olympus) and scanning electron microscopy (Philips XL30; ESEM-TMP). Growth on ISP 2, ISP 5 (Shirling \& Gottlieb, 1966), trypticase soy agar (TSA; Difco) and nutrient agar was also evaluated. Colony colour was determined by comparison with colour chips from the ISCC-NBS colour chart standard samples (Kelly, 1964). The Gram reaction was tested using the nonstaining method as described by Buck (1982).

Strain YIM $45607^{\mathrm{T}}$ formed smooth, circular, convex, opaque and pink-pigmented colonies with entire margins 
that varied in diameter from 0.35 to $1.2 \mathrm{~mm}$ on ISP 2 after 7 days of incubation at $28{ }^{\circ} \mathrm{C}$. The cells were Grampositive, non-spore-forming and non-motile. Light microscopy revealed that cells of strain YIM $45607^{\mathrm{T}}$ formed filaments or showed elementary branching at the early phase of growth $(12 \mathrm{~h})$ and fragmented into short rods during the exponential phase $(24 \mathrm{~h})$. Most cells appeared as cocci in stationary phase $(64 \mathrm{~h})$. Thus, the results confirmed that strain YIM $45607^{\mathrm{T}}$ had a rod-coccus cycle during its growth phase. The strain grew well on ISP 2 and TSA and grew weakly on ISP 5 , but did not grow on nutrient agar.

Utilization of carbohydrates and organic acids was determined by using the methods described by Shirling \& Gottlieb (1966). Decomposition of adenine, casein, hypoxanthine, tyrosine, urea and xanthine was examined by using the methods of Gordon et al. (1974). Decomposition of gelatin, elastin, aesculin and starch was examined by using the methods of Goodfellow \& Pirouz (1982). Enzyme activity tests were performed using API ZYM test kits (bioMérieux). The results were evaluated after incubation at $28{ }^{\circ} \mathrm{C}$ for $48 \mathrm{~h}$. Antibiotic susceptibility was examined as described by Groth et al. (2004) using antibiotic discs (Himedia). Growth at different temperatures, $\mathrm{pH}$ and $\mathrm{NaCl}$ concentrations was determined on ISP 2. Catalase activity was determined by assessing bubble production in $3 \%(\mathrm{v} / \mathrm{v}) \mathrm{H}_{2} \mathrm{O}_{2}$ and oxidase activity was determined using a $1 \%(\mathrm{w} / \mathrm{v})$ solution of tetramethyl-p-phenylenediamine (Kovacs, 1956).

The isolate was positive for the enzymes alkaline phosphatase, esterase C4, esterase lipase C8, lipase C14, $N$-acetyl- $\beta$ glucosaminidase, leucine arylamidase, $\alpha$-glucosidase, $\beta$ glucosidase, naphthol-AS-BI-phosphohydrolase, $\beta$-glucuronidase, $\alpha$-mannosidase and fucosidase and negative for acid phosphatase, cystine arylamidase, valine arylamidase, $\alpha$-galactosidase, $\beta$-galactosidase, $\alpha$-chymotrypsin and trypsin. The strain was resistant to clindamycin $(2 \mu \mathrm{g})$, norfloxacin $(10 \mu \mathrm{g})$ and trimethoprim $(1.25 \mu \mathrm{g})$, but sensitive to amikacin $(30 \mu \mathrm{g})$, amoxicillin $(10 \mu \mathrm{g})$, ampicillin $(10 \mu \mathrm{g})$, ciprofloxacin $(5 \mu \mathrm{g})$, erythromycin $(15 \mu \mathrm{g})$, gentamicin $(10 \mu \mathrm{g})$, netilmicin $(30 \mu \mathrm{g})$, penicillin $\mathrm{G}$ (10 IU), rifampicin $(5 \mu \mathrm{g})$, tetracycline $(30 \mu \mathrm{g})$ (weak), tobramycin $(10 \mu \mathrm{g})$ and vancomycin $(30 \mu \mathrm{g})$. The detailed differential phenotypic properties are listed in Table 1 and other phenotypic characteristics are presented in the species description.

The amino acid and sugar contents of cell walls were determined according to the procedures described by Staneck \& Roberts (1974). Mycolic acids were extracted and analysed according to the protocol of Minnikin et al. (1975) with $R$. equi DSM $20307^{\mathrm{T}}$ as the reference strain. Polar lipids were extracted as described by Minnikin et al. (1979) and identified by two-dimensional TLC and

Table 1. Differentiating characteristics between strain YIM $45607^{\top}$ and its closest phylogenetic neighbours

Strains: 1, YIM $45607^{\mathrm{T}} ; 2$, R. equi DSM $20307^{\mathrm{T}} ; 3$, R. opacus DSM $43205^{\mathrm{T}} ; 4$, R. wratislaviensis DSM 44107 ${ }^{\mathrm{T}} ; 5$, R. triatomae DSM $44892^{\mathrm{T}}$. All results are from this study except those for $R$. triatomae DSM $44892^{\mathrm{T}}$ (taken from Yassin, 2005). +, Positive; - negative; w, weakly positive. All of the strains are positive for utilization of sodium citrate, glucose and acetate. All of the strains are negative for hydrolysis of casein, elastin and hypoxanthine.

\begin{tabular}{|c|c|c|c|c|c|}
\hline Characteristic & 1 & 2 & 3 & 4 & 5 \\
\hline Growth cycle ${ }^{*}$ & $\mathrm{H}-\mathrm{RC}$ & $\mathrm{H}-\mathrm{RC}$ & $\mathrm{H}-\mathrm{RC}$ & EB-RC & $\mathrm{H}-\mathrm{RC}$ \\
\hline \multicolumn{6}{|l|}{ Hydrolysis of: } \\
\hline Tyrosine & + & - & + & + & - \\
\hline Urea & + & + & + & + & - \\
\hline \multicolumn{6}{|c|}{ Utilization as sole carbon source of: } \\
\hline Lactose & + & - & + & + & - \\
\hline Mannitol & + & - & + & + & - \\
\hline myo-Inositol & + & - & + & + & - \\
\hline Raffinose & $\mathrm{w}$ & - & + & + & - \\
\hline Rhamnose & + & - & + & + & - \\
\hline Sodium gluconate & - & - & + & + & - \\
\hline Xylose & + & - & + & + & - \\
\hline Growth at $37{ }^{\circ} \mathrm{C}$ & + & + & - & - & + \\
\hline
\end{tabular}

${ }^{\star}$ H-RC, Hypha-rod/coccus; EB-RC, elementary branching-rod/coccus. 
spraying with specific reagents (Collins \& Jones, 1980). Menaquinones were extracted by using the method of Collins et al. (1977) and analysed by HPLC as described by Tamaoka et al. (1983). Biomass for quantitative fatty acid analysis of strain YIM $45607^{\mathrm{T}}$ was prepared by scraping growth from TSA plates that had been incubated for 4 days at $28{ }^{\circ} \mathrm{C}$. Analysis of the whole-cell fatty acid pattern followed the methods described by Sasser (1990) using the Microbial Identification System (MIDI).

Strain YIM $45607^{\mathrm{T}}$ contained meso-diaminopimelic acid as the diagnostic diamino acid and arabinose and galactose in cell-wall hydrolysates (cell-wall chemotype IV sensu Lechevalier \& Lechevalier, 1970). The non-diagnostic sugars ribose and glucose were also found in cell-wall hydrolysates. The polar lipids were diphosphatidylglycerol, phosphatidylethanolamine, phosphatidylinositol and phosphatidylinositol mannoside (phospholipid type II sensu Lechevalier et al., 1977). MK-8 $\left(\mathrm{H}_{2}\right)$ was the only menaquinone detected and mycolic acids were present which co-migrated with those of $R$. equi DSM $20307^{\mathrm{T}}$ except for one band. The major fatty acids $(>10 \%)$ were $\mathrm{C}_{16: 0}(44.0 \%), \mathrm{C}_{18: 1} \omega 9 c(25.9 \%)$ and $\mathrm{C}_{16: 1} \omega 7 c(10.2 \%)$. All these chemotaxonomic markers support the assignment of strain YIM $45607^{\mathrm{T}}$ to the genus Rhodococcus.

Genomic DNA extraction and PCR amplification of the $16 \mathrm{~S}$ rRNA gene were performed as described by Li et al. (2007). An almost-complete 16S rRNA gene sequence (1421 bp) of strain YIM $45607^{\mathrm{T}}$ was obtained and aligned with the 16S rRNA gene sequences of other Rhodococcus species (obtained from GenBank/EMBL/DDBJ) by using CLUSTAL_X (Thompson et al., 1997). Phylogenetic analysis was performed using the software package MEGA 3.1 (Kumar et al., 2004). Distances (using distance options according to Kimura's two-parameter model; Kimura, 1983) were calculated and clustering was performed with the neighbour-joining method (Saitou \& Nei, 1987). Bootstrap analysis (1000 resamplings) was used to evaluate the tree topology of the neighbour-joining data (Felsenstein, 1985).

Phylogenetic analysis showed that strain YIM $45607^{\mathrm{T}}$ formed a distinct subclade within the genus Rhodococcus with R. equi DSM $20307^{\mathrm{T}}$ (Fig. 1), and this result further confirmed the affiliation of strain YIM $45607^{\mathrm{T}}$ to the genus Rhodococcus. The 16S rRNA gene sequence similarities of strain YIM $45607^{\mathrm{T}}$ to type strains of species of the genus Rhodococcus with validly published names were below $97.0 \%$ except those of Rhodococcus opacus, $R$. wratislaviensis, $R$. triatomae and $R$. equi (97.4, 97.6, 97.6 and $98.2 \%$, respectively). The $\mathrm{G}+\mathrm{C}$ content of the genomic DNA was determined by HPLC according to Mesbah et al. (1989) and a value of $64.9 \mathrm{~mol} \%$ was measured.

To determine whether strain YIM $45607^{\mathrm{T}}$ represents a distinct species of the genus Rhodococcus, DNA-DNA hybridization was performed by applying the method of $\mathrm{He}$ et al. (2005) with five replications for each sample. Strain YIM $45607^{\mathrm{T}}$ displayed low DNA-DNA reassociation with

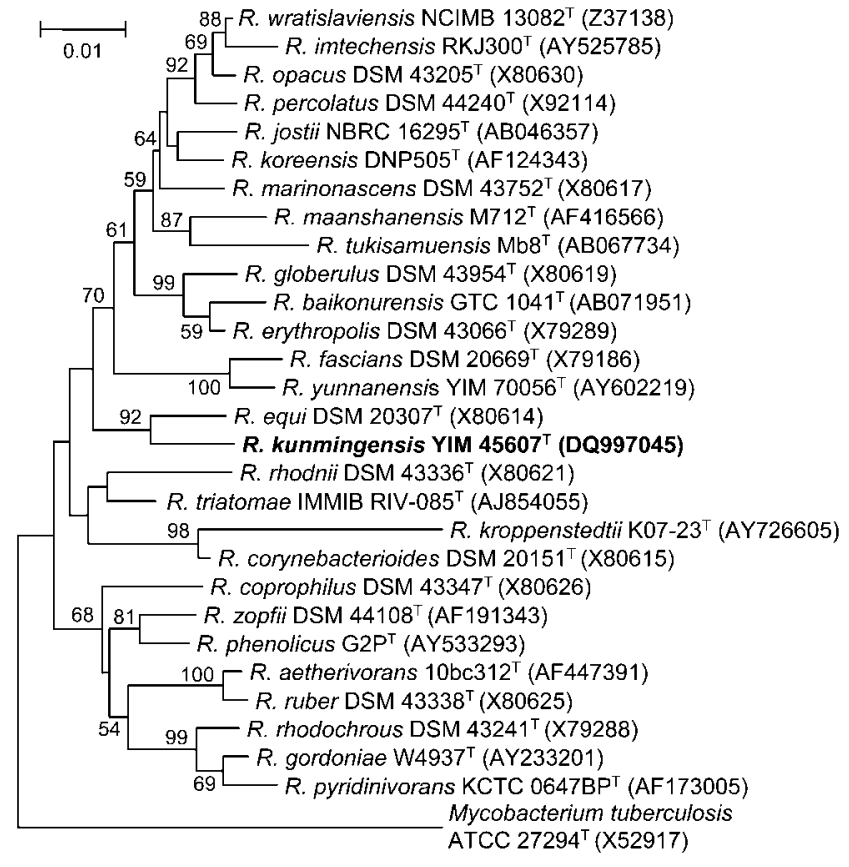

Fig. 1. Neighbour-joining tree showing the phylogenetic relationships between strain YIM $45607^{\top}$ and related species of the genus Rhodococcus, based on 16S rRNA gene sequences. Numbers on branch nodes are bootstrap values (percentages of 1000 replicates). Bar, 1 substitution per 100 nucleotide positions.

R. opacus DSM $43205^{\mathrm{T}}(46.5 \pm 4 \%)$, R. wratislaviensis DSM $44107^{\mathrm{T}} \quad(40.3 \pm 7 \%), \quad R$. triatomae DSM $44892^{\mathrm{T}}$ $(34.4 \pm 5 \%)$ and $R$. equi DSM $20307^{\mathrm{T}}(35.4 \pm 10 \%)$ (means $\pm \mathrm{SD}$ ). These results were consistent with the conclusion drawn by Yassin (2005) that representatives of Rhodococcus species with 16S rRNA gene sequence similarities greater than $98 \%$ may share whole genomic DNA relatedness values well below the $70 \%$ cut-off point recommended for delineation of bacterial genomic species (Wayne et al., 1987).

The genotypic and phenotypic data (Table 1) described above suggest that strain YIM $45607^{\mathrm{T}}$ could be distinguished from its closest phylogenetic neighbours. Therefore, strain YIM $45607^{\mathrm{T}}$ represents a novel species of the genus Rhodococcus, for which the name Rhodococcus kunmingensis sp. nov. is proposed.

\section{Description of Rhodococcus kunmingensis sp. nov.}

Rhodococcus kunmingensis (kun.ming.en'sis. N.L. masc. adj. kunmingensis pertaining to Kunming, a city of Yunnan in south-west China).

Cells are Gram-positive, aerobic, acid-fast, non-sporeforming and non-motile. Forms filaments or shows elementary branching in the early growth phase and occurs mostly as cocci in stationary phase. Colonies are pink 
pigmented (approx. $0.35-1.2 \mathrm{~mm}$ in diameter after 7 days of incubation at $28{ }^{\circ} \mathrm{C}$ ), circular and convex with a smooth surface on ISP 2 and light-pink pigmented (approx. 0.23$1.35 \mathrm{~mm}$ in diameter after 7 days of incubation at $28{ }^{\circ} \mathrm{C}$ ) on TSA. Growth occurs at $10-37{ }^{\circ} \mathrm{C}$ and $\mathrm{pH}$ 7.0-7.5; no growth below $10{ }^{\circ} \mathrm{C}$ or above $37{ }^{\circ} \mathrm{C}$. Growth occurs in the presence of $7 \% \mathrm{NaCl}$, but not above $7 \% \mathrm{NaCl}$. Catalasepositive, oxidase-negative. $\mathrm{H}_{2} \mathrm{~S}$ is not produced and nitrate is reduced. Decomposes adenine, aesculin, L-arginine, Lasparagine, gelatin, L-histidine, L-proline, L-tyrosine and urea, but not casein, elastin, hypoxanthine or starch. Utilizes amygdalin, L-arabinose, butanediol, fructose, Dglucose, lactose, mannose, melibiose, sodium benzoate, sodium malate, sodium succinate, sucrose, tartrate, xylitol and L-xylose as sole carbon sources and utilizes raffinose and trehalose weakly, but does not utilize chitin, maltose, oxalate or propionate. Contains meso-diaminopimelic acid, and arabinose and galactose are present in cell-wall hydrolysates. MK- $8\left(\mathrm{H}_{2}\right)$ is the predominant menaquinone. The phospholipid pattern consists of diphosphatidylglycerol, phosphatidylethanolamine, phosphatidylinositol and phosphatidylinositol mannoside. Mycolic acids are present. The fatty acid profile $(>1 \%)$ is as follows: $\mathrm{C}_{16: 0}(44.0 \%)$, $\mathrm{C}_{18: 1} \omega 9 c(25.9 \%), \mathrm{C}_{16: 1} \omega 7 c(10.2 \%), \mathrm{C}_{14: 0}(6.9 \%), 10-$ methyl $\mathrm{C}_{18: 0}$ (tuberculostearic acid) $(4.8 \%), \mathrm{C}_{18: 0}(2.3 \%)$, $\mathrm{C}_{17: 1} \omega 8 c(1.5 \%)$ and $\mathrm{C}_{17: 0}(1.4 \%)$. The $\mathrm{G}+\mathrm{C}$ content of genomic DNA of the type strain is $64.9 \mathrm{~mol} \%$.

The type strain, YIM $45607^{\mathrm{T}}\left(=\right.$ KCTC $19149^{\mathrm{T}}=\mathrm{DSM}$ $45001^{\mathrm{T}}$ ), was isolated from a rhizosphere soil sample collected in Kunming, south-west China.

\section{Acknowledgements}

This research was supported by the National Basic Research Program of China (no. 2004CB719601), the National Natural Science Foundation of China (nos 30560001 and 30600001), the Key Project of the Chinese Ministry of Education (no. 206139), the Yunnan Provincial International Cooperative Program (no. 2005GH21) and the Ministry of Science and Technology, PR China (2006DFA33550). W.-J. L. was also supported by the Program for New Century Excellent Talent in University (NCET).

\section{References}

Buck, J. D. (1982). Nonstaining (KOH) method for determination of Gram reactions of marine bacteria. Appl Environ Microbiol 44, 992-993.

Collins, M. D. \& Jones, D. (1980). Lipids in the classification and identification of coryneform bacteria containing peptidoglycans based on 2,4-diaminobutyric acid. J Appl Bacteriol 48, 459-470.

Collins, M. D., Pirouz, T., Goodfellow, M. \& Minnikin, D. E. (1977). Distribution of menaquinones in actinomycetes and corynebacteria. J Gen Microbiol 100, 221-230.

Felsenstein, J. (1985). Confidence limits on phylogenies: an approach using the bootstrap. Evolution 39, 783-791.

Goodfellow, M. \& Pirouz, T. (1982). Numerical classification of sporoactinomycetes containing meso-diaminopimelic acid in the cell wall. J Gen Microbiol 128, 503-527.

Gordon, R. E., Barnett, D. A., Handerhan, J. E. \& Pang, C. H.-N. (1974). Nocardia coeliaca, Nocardia autotrophica, and the nocardin strain. Int J Syst Bacteriol 24, 54-63.
Groth, I., Rodríguez, C., Schütze, B., Schmitz, P., Leistner, E. \& Goodfellow, M. (2004). Five novel Kitasatospora species from soil: Kitasatospora arboriphila sp. nov., $K$. gansuensis sp. nov., $K$. nipponensis sp. nov., K. paranensis sp. nov. and $K$. terrestris sp. nov. Int J Syst Evol Microbiol 54, 2121-2129.

He, L., Li, W., Huang, Y., Wang, L. M., Liu, Z. H., Lanoot, B. J., Vancanneyt, M. \& Swings, J. (2005). Streptomyces jietaisiensis sp. nov., isolated from soil in northern China. Int J Syst Evol Microbiol 55, 1939-1944.

Kelly, K. L. (1964). Inter-Society Color Council - National Bureau of Standards Color-Name Charts Illustrated with Centroid Colors. Washington, DC: US Government Printing Office.

Kimura, M. (1983). The Neutral Theory of Molecular Evolution. Cambridge: Cambridge University Press.

Kovacs, N. (1956). Identification of Pseudomonas pyocyanea by oxidase reaction. Nature 178, 703-704.

Kumar, S., Tamura, K. \& Nei, M. (2004). MEGA3: integrated software for molecular evolutionary genetics analysis and sequence alignment. Brief Bioinform 5, 150-163.

Lechevalier, M. P. \& Lechevalier, H. A. (1970). Chemical composition as a criterion in the classification of aerobic actinomycetes. Int J Syst Bacteriol 20, 435-443.

Lechevalier, M. P., De Bièvre, C. \& Lechevalier, H. A. (1977). Chemotaxonomy of aerobic actinomycetes: phospholipid composition. Biochem Syst Ecol 5, 249-260.

Li, W.-J., Xu, P., Schumann, P., Zhang, Y.-Q., Pukall, R., Xu, L.-H., Stackebrandt, E. \& Jiang, C.-L. (2007). Georgenia ruanii sp. nov., a novel actinobacterium isolated from forest soil in Yunnan (China), and emended description of the genus Georgenia. Int J Syst Evol Microbiol 57, 1424-1428.

McMinn, E. J., Alderson, G., Dodson, H. I., Goodfellow, M. \& Ward, A. C. (2000). Genomic and phenomic differentiation of Rhodococcus equi and related strains. Antonie van Leeuwenhoek 78, 331-340.

Mesbah, M., Premachandran, U. \& Whitman, W. B. (1989). Precise measurement of the $\mathrm{G}+\mathrm{C}$ content of deoxyribonucleic acid by highperformance liquid chromatography. Int J Syst Bacteriol 39, 159167.

Minnikin, D. E., Alshamaony, L. \& Goodfellow, M. (1975). Differentiation of Mycobacterium, Nocardia, and related taxa by thin-layer chromatographic analysis of whole-organism methanolysates. J Gen Microbiol 88, 200-204.

Minnikin, D. E., Collins, M. D. \& Goodfellow, M. (1979). Fatty acid and polar lipid composition in the classification of Cellulomonas, Oerskovia and related taxa. J Appl Bacteriol 47, 87-95.

Saitou, N. \& Nei, M. (1987). The neighbor-joining method: a new method for reconstructing phylogenetic trees. Mol Biol Evol 4, 406425.

Sasser, M. (1990). Identification of bacteria by gas chromatography of cellular fatty acids. USFCC Newsl 20, 16.

Shirling, E. B. \& Gottlieb, D. (1966). Methods for characterization of Streptomyces species. Int J Syst Bacteriol 16, 313-340.

Stackebrandt, E., Rainey, F. A. \& Ward-Rainey, N. L. (1997). Proposal for a new hierarchic classification system, Actinobacteria classis nov. Int J Syst Bacteriol 47, 479-491.

Staneck, J. L. \& Roberts, G. D. (1974). Simplified approach to identification of aerobic actinomycetes by thin-layer chromatography. Appl Microbiol 28, 226-231.

Suzuki, S., Okuda, T. \& Komatsubara, S. (1999). Selective isolation and distribution of Sporichthya strains in soil. Appl Environ Microbiol 65, 1930-1935. 
Tamaoka, J., Katayama-Fujimura, Y. \& Kuraishi, H. (1983). Analysis of bacterial menaquinone mixtures by high performance liquid chromatography. J Appl Bacteriol 54, 31-36.

Thompson, J. D., Gibson, T. J., Plewniak, F., Jeanmougin, F. \& Higgins, D. G. (1997). The CLUSTAL_X windows interface: flexible strategies for multiple sequence alignment aided by quality analysis tools. Nucleic Acids Res 25, 4876-4882.
Wayne, L. G., Brenner, D. J., Colwell, R. R., Grimont, P. A. D., Kandler, O., Krichevsky, M. I., Moore, L. H., Moore, W. E. C., Murray, R. G. E. \& other authors (1987). International Committee on Systematic Bacteriology. Report of the ad hoc committee on reconciliation of approaches to bacterial systematics. Int J Syst Bacteriol 37, 463-464.

Yassin, A. F. (2005). Rhodococcus triatomae sp. nov., isolated from a blood-sucking bug. Int J Syst Evol Microbiol 55, 1575-1579. 